\title{
In Defence of Wetlands
}

Many people think of a marsh as an untidy bit of waste land, crawling with mosquitoes and other pests. Others, who understand the value of a marsh, are trying to correct this concept by showing the marsh in its true light as a complex and interesting natural community. A recent article by Dr. R. W. Nero in the Modern Instructor (Vol. 28: 373-77) introduces this concept of a marsh to the young people in Saskatchewan schools; another article, in the last issue of Natural History (Vol. 69: 4: 33-43), encourages the reader to see in a marsh "a great pageant of natural history."

The most obvious forms of life supported by our marshes, and those that have most immediate economic importance, are, of course, the furbearing animals and waterfowl. A very large proportion of the major game species of ducks breed here in the three prairie provinces. For this reason many dollars have been spent by Ducks Unlimited in a valiant effort to build marshes. Surely the real solution is not to build marshes at enormous expense, but to preserve existing marshes at very little expense.

Anyone who doubts the need for preserving wetlands should examine some of the most recent reports of the increasing decline of our waterfowl. The Report of the Committee on Applied Ecology (1960. Bull. Ecological Soc. Amer., 41:25-29) surveys the situation as follows:

"Since World War II, in the northern prairie states and the prairie provinces of Canada, organized drainage has steadily turned marshes into cropfields. In this, the primary breeding ground of the continent for game ducks, public subsidies have been the means of adding to graincrop surpluses while reducing the waterfowl that is in ever-greater recreational demand ... Breeding populations of mallards, pintails, and canvasbacks were down significantly in 1958, and a year later had undergone additional declines. The outlook for duck production is the poorest in many years ... In a national wetland survey reported in 1956, the Fish and Wildlife Service stated that some five million acres of waterfowl habitat was in public ownership. It was calculated that a minimum of 12.5 million acres of water and marsh would have to be owned and intensively managed to hold the waterfowl population at the 1955 level ... In 1959, congress refused to remove drainage subsidies that are destroying wetlands in the breeding grounds far faster than these areas can be acquired. To exemplify this trend, in Minnesota and the Dakotas, from 1951 to 1955 , drainage payments under the Agricultural Conservation Program totalled $\$ 5,639,732$ and eliminated 256,700 acres of waterfowl habitat. In the same area during this period the Fish and Wildlife Service spent $\$ 67,613$ for 3,462 acres . . . It is evident that the long-range outlook for waterfowl is not favorable. In terms of ecological knowledge, the problems are readily soluble, since environmental requirements of waterfowl are well understood, and the harvest can be managed on a year-to-year basis. But scientific concepts are not being applied. Effective public policy is being dictated by pressure groups who insist on following old bzhavior patterns of land drainage and the production of surplus crops. This body of opinion shows little interest in values beyond the present or appreciation that outdoor recreation is part of the American living standard."

We should like to be able to say self-righteously that drainage programmes such as those deplored in the committee's report are not endangering the wetlands of Saskatchewan. Unfortunately this is not the case-we have the same conflict between agricultural interests and the broader long-term interests of the conservationist. A recent example of this was the proposed drainage of Warner Lake in the Kelvington area. Our society and two other groups with similar interests-Ducks Unlimited and the Saskatchewan Fish and Game League-presented their arguments against drainage in briefs submitted to the meeting of the local Conservation and Development Area Authority in Kelvington on March 23, 1960. So that each of our members may have the opportunity of evaluating the arguments put forward 
against drainage we are reviewing the three briefs presented at Kelvington:

SNHS BRIEF: This brief maintained that it is unnecessary to drain such lakes as Warner Lake for agricultural purposes since we have a surplus of all agricultural products from wheat to turkeys. There is need, however, for recreational areas and for areas where wildfowl and fur-bearing animals may be raised. Experience in the United States has shown that draining of marshes and shallow lakes so suitable for ducks often resulted in land unsuitable for agriculture. Attempts to re-flood such areas have proved expensive and disappointing because there are no native duck and animal populations left.

A marsh like Warner Lake is valuable as a breeding ground for waterfowl, especially those other than the Mallard (which can manage with a dugout or pothole). Winter surveys by the U.S. Fish and Wildlife Service show the 1960 Redhead population $72 \%$ below the already low level of 1959, Mallard population down $22 \%$, Green-winged Teal, $32 \%$, Blue-winged Teal, 44\%, and Pintails, $27 \%$.

Two counts made at Warner Lake in June, 1959, showed over 1,000 ducks using the area. Figures are also given to show that muskrats had been harvested here in significant numbers over the years.

Shallow lakes and marshes such as Warner Lake provide valuable habitats for wildlife and should be preserved so that the best use possible will be made of the area.

DUCKS UNLIMITED BRIEF: This group is concerned primarily with the production of migratory wildfowl. They point out that "past history would indicate that Warner Lake had sufficient permanency to produce waterfowl $75 \%$ of the time. With the lowering of the outlet in the 1920 's and again in 1955 the permanency has been reduced to an estimated 60\%." Such lakes as Warner Lake are valuable because they produce up to 1,000 pounds of aquatic seeds per acre. It was estimated that Warner Lake last year produced aquatic food for ducks equal in food value to 1,000 bushels of grain. This group also doubts the value of the land for agriculture; therefore, why not consider the area a resource which is best utilized for the production of aquatic foods as at present?

SASK. FISH AND GAME LEAGUE BRIEF: This brief points out that hunting has become an important industry in Saskatchewan bringing in an estimated $\$ 8,000,000$ a year. "If present subsidized and other drainage policies continue it would appear that the government departments concerned with recreation and travel will be doomed to failure."

The removal of wetlands such as Warner Lake increases the conflict between those interested in waterfowl production and farmers. The more lakes, sloughs, etc., that are retained the less will be the loss to the farmers caused by field-feeding ducks. Management of wetlands to decrease crop damage has proved successful along the three western flyways; "managed" areas of water keep the ducks away from vulnerable swaths.

This brief warns that drainage of surface water affects the water table causing wells to go dry. Farmers interested in the Farm Improvement Act will appreciate the risk involved here.

It is unwise to allow a few landowners to jeopardize the future of successful wildlife management and endanger the supply of water for agricultural and domestic purposes.

\section{Protection Given Hawks and Owls}

During the last sitting of the Sask. Legislature the Game Act was amended to protect all hawks and owls, except that Snowy Owls, Great Horned Owls and Goshawks may be destroyed from November 1 to March 31.

\section{SPECIAL PUBLICATIONS}

\#1. Guide to Sask. Mammals .50

\#2. Birds of the Sask River ... 1.50

Write to

Blue Jay editor, 2335 Athol St., Regina. 